\title{
Effect of base media, FSH and anti-Müllerian hormone (AMH) alone or in combination on the growth of pig preantral follicles in vitro
}

Efeito do meio de base, FSH e hormônio anti-Müllleriano (AMH) isoladamente ou em combinação no crescimento de folículos pré-antrais suínos in vitro

Efecto del medio base, la FSH y la hormona antimülleriana (AMH) solas o en combinación sobre el crecimiento de los folículos preantrales porcinos in vitro

Rebeca Magalhães Pedrosa Rocha ORCID: https://orcid.org/0000-0002-4991-3180 State University of Ceara, Brazil E-mail: rebecarocha@unilab.edu.br Marcello Rubessa ORCID: https://orcid.org/0000-0003-4113-0883 University of Illinois, USA E-mail: rubessa@illinois.edu

Laritza Ferreira de Lima ORCID: https://orcid.org/0000-0001-6391-7113 State University of Ceara, Brazil

E-mail: laritza_lima@yahoo.com.br

Ana Flávia Bezerra da Silva ORCID: https://orcid.org/0000-0002-0450-6039 State University of Ceara, Brazil

E-mail: af.biomedica@gmail.com

Rebecca Winters

ORCID: https://orcid.org/0000-0002-0012-7584 University of Illinois, USA

E-mail: winters9@illinois.edu

Kathryn Polkoff

ORCID: https://orcid.org/0000-0001-6227-622X University of Illinois, USA E-mail: polkoff2@illinois.edu

Derek Milner

ORCID: https://orcid.org/0000-0001-7437-2235 University of Illinois, USA

E-mail: d_milner@life.illinois.edu

Cláudio Cabral Campello

ORCID: https://orcid.org/0000-0001-8808-4832

State University of Ceara, Brazil

E-mail: claudio.campello@uece.br

José Ricardo de Figueiredo

ORCID: https://orcid.org/0000-0002-5139-0964

State University of Ceara, Brazil

E-mail: jrf.lamofopapapers@gmail.com

Matthew Wheeler

ORCID: https://orcid.org/0000-0001-5589-357X

University of Illinois, USA

E-mail: mbwheele@illinois.edu

\begin{abstract}
To compare the efficiency of North Carolina State University medium 23 (NCSU23) and Alpha Minimum Essential Medium ( $\alpha$-MEM) as a base medium, and to evaluate the effects of Anti-Müllerian Hormone (AMH) alone or in combination with Follicle Stimulating Hormone (FSH) on the in vitro development and steroid production of isolated porcine preantral follicles. Porcine secondary follicles were cultured in NCSU23 or $\alpha$-MEM media for 4 days. Once $\alpha$-MEM was determined to be the optimal culture medium, secondary follicles were cultured in $\alpha$-MEM alone or supplemented with FSH $(1.5 \mathrm{ng} / \mathrm{mL})$, AMH $(50 \mathrm{ng} / \mathrm{mL})$ or the combination of the two hormones. Follicle development was evaluated by measuring follicular growth, morphology and hormone production. There was no difference between the media NCSU23 and $\alpha$-MEM in terms of follicle survival and growth $(\mathrm{P}>0.05)$. However, at
\end{abstract}


day 2 , the antrum formation rate tended to be $(\mathrm{P}<0.074)$ higher in $\alpha$-MEM than NCSU23. At day 4 of culture, the estradiol and progesterone secretion were higher in $\alpha$-MEM than NCSU23 $(\mathrm{P}<0.01$ ), while the opposite was observed for testosterone $(\mathrm{P}<0.01)$. The addition of AMH and/or FSH did not affect follicular survival and growth. Nevertheless, the secretion of estradiol and progesterone induced by FSH was reduced with AMH $(\mathrm{P}<0.01) . \alpha-\mathrm{MEM}$ is a more effective base medium than NCSU23 for the in vitro follicular development of pig preantral follicles and AMH reduces the steroid production induced by FSH.

Keywords: Culture; Esteroids; Folliculogenesis; Porcine.

\title{
Resumo
}

Comparar a eficiência do meio 23 da Universidade Estadual da Carolina do Norte (NCSU23) e do meio alfa essencial mínimo ( $\alpha$-MEM) como meio de base e avaliar os efeitos do hormônio anti-Mülleriano (AMH) sozinho ou em combinação com o hormônio folículo estimulante (FSH) no desenvolvimento in vitro e na produção de esteroides de folículos pré-antrais suínos isolados. Folículos secundários suínos foram cultivados em meio NCSU23 ou $\alpha$-MEM por 4 dias. Uma vez que $\alpha$-MEM foi determinado ser o meio de cultivo ideal, os folículos secundários foram cultivados em $\alpha$-MEM sozinho ou suplementado com FSH (1,5 ng/mL), AMH (50 ng/mL) ou na combinação dos dois hormônios. O desenvolvimento folicular foi avaliado medindo o crescimento folicular, a morfologia e a produção hormonal. Não houve diferença entre os meios NCSU23 e $\alpha$-MEM em termos de sobrevivência e crescimento folicular $(\mathrm{P}>0,05)$. No entanto, no dia 2, a taxa de formação de antro tendeu a ser $(\mathrm{P}<0,074)$ maior em $\alpha$-MEM do que NCSU23. No dia 4 de cultivo, a secreção de estradiol e progesterona foram maiores no $\alpha$-MEM do que no NCSU23 ( $\mathrm{P}<0,01)$, enquanto o oposto foi observado para a testosterona $(\mathrm{P}<0,01)$. A adição de AMH e/ou FSH não afetou a sobrevivência e o crescimento folicular. No entanto, a secreção de estradiol e progesterona induzida pelo FSH foi reduzida com o AMH $(\mathrm{P}<0,01)$. $\alpha$-MEM é um meio de base mais eficaz do que o NCSU23 para o desenvolvimento folicular in vitro de folículos pré-antrais suínos e o AMH reduz a produção de esteroides induzida por FSH.

Palavras-chave: Cultivo; Esteroides; Foliculogênese; Suíno.

\begin{abstract}
Resumen
Comparar la eficiencia del medio 23 de la Universidad Estatal de Carolina del Norte (NCSU23) y el medio esencial alfa mínimo $(\alpha$-MEM) como medio base y evaluar los efectos de la hormona antimülleriana (AMH) sola o en combinación con el folículo estimulante de la hormona (FSH) sobre el desarrollo in vitro y la producción de esteroides a partir de folículos preantrales porcinos aislados. Se cultivaron folículos secundarios porcinos en medio NCSU23 o $\alpha$-MEM durante 4 días. Una vez que se determinó que $\alpha$-MEM era el medio de cultivo ideal, los folículos secundarios se cultivaron en $\alpha$-MEM solo o suplementados con FSH (1,5 ng/ml), AMH (50 ng/ml) o una combinación de las dos hormonas. El desarrollo folicular se evaluó midiendo el crecimiento folicular, la morfología y la producción de hormonas. No hubo diferencia entre los medios NCSU23 y $\alpha$-MEM en términos de supervivencia y crecimiento folicular $(\mathrm{P}>0,05)$. Sin embargo, en el día 2, la tasa de formación de antro tendió a ser $(\mathrm{P}<0.074)$ más alta en $\alpha$-MEM que en NCSU23. En el día 4 de cultivo, la secreción de estradiol y progesterona fue mayor en $\alpha$-MEM que en NCSU23 ( $\mathrm{P}<0,01)$, mientras que se observó lo contrario para la testosterona $(\mathrm{P}<0,01)$. La adición de AMH y/o FSH no afectó la supervivencia y el crecimiento folicular. Sin embargo, la secreción de estradiol y progesterona inducida por FSH se redujo con AMH $(\mathrm{P}<0,01)$. $\alpha$-MEM es un medio de fondo más eficaz que NCSU23 para el desarrollo folicular in vitro de folículos preantrales porcinos y la AMH reduce la producción de esteroides inducida por FSH.
\end{abstract}

Palabras clave: Cultivo; Esteroides; Foliculogénesis; Porcino.

\section{Introduction}

Advances in reproductive biotechnology have increased the demand for large quantities of fertilizable oocytes. Thus, research has focused on developing a preantral follicular culture system that can be used to study early folliculogenesis and to serve as a source of oocytes for in vitro embryo production (Figueiredo, Rodrigues, Silva, \& Santos, 2011; Marino et al., 2019). To date, birth of live pups after fertilization of oocytes from cultured primordial follicles was obtained in the mouse (O’Brien, Pendola, \& Eppig, 2003). However, similar success has not been reported in large mammals. In pigs, to our knowledge, in vitro experiments with preantral follicles are few and with limited success (Wu, Emery, \& Carrell, 2001; Mao et al., 2002; Mao et al., 2004; Wu, Xu, \& Wang, 2007; Tasaki, Iwata, Sato, Monji, \& Kuwayama, 2013; Lima et al., 2017; Cao et al., 2019).

The first step to develop a culture system is to define a base culture medium followed by the studies investigating the effect of different supplements alone or in combination. Although there are investigations comparing the efficiency of culture 
media in pigs, such as the North Carolina State University medium 23 (NCSU23) and the Tissue Culture Medium 199 (TCM199; Mao et al., 2002; Pyoos, Maqhashu, Scholtz, \& Nedambale, 2018), there are no studies comparing the effects of NCSU23 medium and the Alpha Minimum Essential Medium ( $\alpha$-MEM) on the in vitro development of pig preantral follicles under the same culture conditions.

In addition to attempt to determine a suitable base medium, it is necessary to investigate the role of different supplements added to the culture medium of preantral follicles. In this case, the role of Anti-Müllerian Hormone (AMH), which belongs to the transforming growth factor beta superfamily, has not fully elucidated in the different species. Studies in mice and human revealed stimulatory (Schmidt, Kryger-Baggesen, Byskov, \& Andersen, 2005; Kano et al., 2017; Sonigo, Beau, Grynberg, \& Binart, 2019) and inhibitory (Durlinger et al., 2002; Carlsson et al., 2006; Nilsson, Schindler, Savenkova, \& Skinner, 2011; Pankhurst, 2017; Pankhurst et al., 2018) actions of AMH on primordial follicle activation. Furthermore, the relations of AMH with a well-known regulator of folliculogenesis, Follicle Stimulating Hormone (FSH), is not fully known either. However, to the best of our knowledge, investigations regarding the relationship between FSH and AMH during in vitro culture of isolated preantral follicles in pigs have not been performed. Therefore, for a better understanding of in vitro folliculogenesis in pigs, the aims of this study were to investigate the efficiency of NCSU23 and $\alpha$-MEM as a base medium, as well as to evaluate the effects of AMH alone or in combination with FSH on the in vitro follicular growth, survival, and steroid production (estradiol, progesterone and testosterone).

\section{Methodology}

\subsection{Research Ethics}

Alternatives to animal testing are the development and implementation of test methods that avoid the use of live animals. One of the major alternatives to in vivo animal testing is in vitro cell culture. In line with this ethical issue, the present basic research aimed to evaluate the effects of the base media and the addition of hormones (AMH and FSH) on in vitro folliculogenesis using porcine follicles recovered from slaughterhouse ovaries. This source of ovarian material represents a byproduct of the food industry and is more readily acceptable than euthanasia of animals specifically for scientific purposes.

\subsection{Reagents and Media}

Unless otherwise stated, all reagents were purchased from Sigma-Aldrich (USA).

\subsection{Ovary Collection}

Ovaries $(n=120)$ from prepubertal gilts were collected at a local abattoir and transported to the laboratory in physiological saline at $30-35^{\circ} \mathrm{C}$. The ovaries were washed with $70 \%$ ethanol for $10 \mathrm{~s}$, followed by a wash with saline solution supplemented with penicillin $(100 \mu \mathrm{g} / \mathrm{mL})$ and streptomycin (100 $\mu \mathrm{g} / \mathrm{mL}$; Lima et al., 2017; Yu et al., 2018).

\subsection{Follicle Isolation and In vitro Culture of Preantral Follicles}

The in vitro culture system used herein was performed according to the protocol of Wu, Emery and Carrell (2001), with slight modifications. Once in the laboratory, the surrounding fatty tissues and ligaments were stripped from the ovaries. Ovarian cortical slices (1-2 mm thick) were cut from the ovarian surface using a surgical blade under sterile conditions and subsequently placed in holding medium consisting of medium H 199 (Lonza 12-117F) with antibiotics and 3\% bovine serum albumin. Secondary follicles $(250-330 \mu \mathrm{m})$ without antral cavities, two to three layers of granulosa cells, and a visible oocyte were mechanically isolated by microdissection using 26-gauge needles and transferred to $300 \mu \mathrm{L}$ droplets containing basic culture medium. The follicles were randomly divided among the treatment groups. Then, follicles ( 3 per well) were placed in 
$280 \mu \mathrm{L}$ of culture medium in 48 -well plates and incubated at $39^{\circ} \mathrm{C}$ and $5 \% \mathrm{CO}_{2}$ in air for 4 days. Approximately $35-40$ follicles per group were evaluated.

The basic control medium was supplemented with $3.5 \mu \mathrm{g} / \mathrm{mL}$ insulin, $10 \mu \mathrm{g} / \mathrm{mL}$ transferrin, $100 \mu \mathrm{g} / \mathrm{mL}$ L-ascorbic acid, $7.5 \%$ porcine serum, and $1.5 \mathrm{ng} / \mathrm{mL} \mathrm{FSH}$. The culture medium was partially replaced ( $140 \mu \mathrm{L})$ every 2 days with freshly prepared culture medium. The medium obtained on Days 2 and 4 was stored at $-20^{\circ} \mathrm{C}$ for assessing hormone content.

\subsection{Morphological Evaluation of Follicle Development}

The morphological aspects of all preantral follicles were assessed every 2 days using a pre-calibrated ocular micrometer in a stereomicroscope (Nikon DIAPHOT 200) at 100x magnification. Only those follicles showing an intact basement membrane, with bright and homogeneous granulosa cells and an absence of morphological signs of degeneration, were classified as morphologically normal. Every 2 days of culture (days 0, 2, and 4), the following characteristics were analyzed in the morphologically normal follicles: (1) antral cavity formation, defined as the emergence of a visible translucent cavity within the granulosa cell layers, and (2) the diameter of morphologically normal follicles, measured from the basement membrane, which included two perpendicular measures of each preantral follicle, with the aid of Carl Zeiss Microscopy BmbH 2011 and analyzed by Zen Lite program under 100x magnification (Lima et al., 2017).

\subsection{Hormone Assays}

Spent medium was collected at days 2 and 4 and stored at $-80^{\circ} \mathrm{C}$ for subsequent estradiol (E2), progesterone (P4) and testosterone (T) assays (Lima et al., 2017). Steroid concentrations were determined by Enzyme-Linked ImmunoSorbent Assay (ELISA) kits: Arbor Assays K030-H1 (E2), K025-H1 (P4) and K032-H1 (T). The lower detection limits were, respectively: $26.5 \mathrm{pg} / \mathrm{mL}$ for $\mathrm{E} 2,52.9 \mathrm{pg} / \mathrm{mL}$ for $\mathrm{P} 4$, and $30.6 \mathrm{pg} / \mathrm{mL}$ for $\mathrm{T}$.

\subsection{Experimental Design}

\subsubsection{Experiment I}

In order to verify the effects of different culture media during in vitro culture of porcine preantral follicles, isolated secondary follicles $(\mathrm{n}=65)$ were randomly distributed into two groups: $\alpha$-MEM $(\mathrm{n}=35)$ and NCSU23 $(\mathrm{n}=30)$. Follicle development was evaluated by morphological and growth analysis, and steroids production. Each condition was replicated three times.

\subsubsection{Experiment II}

Once the optimal culture medium for the in vitro development of porcine follicles was determined ( $\alpha$-MEM), experiment II was carried out in order to evaluate the effects of AMH alone or in combination with FSH on the in vitro growth and survival of isolated porcine follicles, as well as on steroid production by these follicles. Therefore, isolated secondary follicles $(\mathrm{n}=170)$ were randomly distributed in the following treatments: $\alpha-\mathrm{MEM}^{+}$(control medium), $\alpha-\mathrm{MEM}^{+}$supplemented with FSH at $1.5 \mathrm{ng} / \mathrm{mL}, \alpha-\mathrm{MEM}^{+}$supplemented with AMH (R\&D Systems, Inc., USA) at $50 \mathrm{ng} / \mathrm{mL}$, or the association AMH + FSH. A total of 40-45 follicles were cultured in each of the four conditions. Each condition was replicated nine times.

\subsection{Statistical Analysis}

Data for continuous variables (follicle diameter and growth rate) were initially evaluated for homoscedasticity and homogeneity (by Bartlett's and Shapiro-Wilk tests, respectively) to confirm requirements underlying the analysis of variance. Then, ANOVA was carried out according to a $3 \times 2$ factorial arrangement of groups time of culture ( 0 or 4 days) as the main 
effects. The model used was $\mathrm{Yij}=\mu+\mathrm{Pi}+\mathrm{Tj}+(\mathrm{Pi} \mathrm{x} \mathrm{Tj})+\mathrm{eijk}$, where $\mathrm{Yij}=$ dependent variable, $\mu=$ general mean; $\mathrm{Pi}=$ procedure, $\mathrm{Tj}=$ time in culture, $\mathrm{Pi} \times \mathrm{Tj}=$ interaction between procedure and time, and eijk = residual error. When any main effect or interactions were significant, means were compared by Student's-Newman-Keuls test, with results expressed as mean \pm standard error of the mean (SEM). Discrete variables (number of follicular integrity extrusion and antrum formation) were analyzed as dispersion of frequency by chi-square test and results were expressed as percentages.

Data for hormone assays were subjected to analysis of variance using the Generalized Linear Model procedure (SAS, version 9, 1999). Independent variables were the groups ( $\alpha-\mathrm{MEM}^{+}$and NCSU23; $\alpha-\mathrm{MEM}, \mathrm{AMH}, \mathrm{FSH}$ and AMH+FSH). Data were normally distributed. Least square means post hoc test was used to perform statistical multiple comparisons. Statistical significance was defined as $\mathrm{P}<0.05$.

\section{Results}

\subsection{Experiment I: Follicle Survival and Growth}

The percentage of morphologically normal follicles decreased $(\mathrm{P}<0.05)$ from Day 2 to Day 4 in the two tested media, which showed similar percentage of morphologically normal follicles regardless the culture time (Table 1; P > 0.05). Table 2 depicts the antrum formation and follicle growth after in vitro culture of pig preantral follicles in $\alpha$-MEM and NCSU23 media. The percentage of antrum formation tends to be $(\mathrm{P}<0.074)$ higher at day 2 in $\alpha$-MEM than NCSU23. However, follicle growth did not differ $(\mathrm{P}>0.05)$ between the tested base media. Nevertheless, for both media follicular diameter increased significantly from day 0 to day 4 of culture. 
Table 1 - Percentages of morphologically normal, extruded and degenerated follicles after 4 days of culture in $\alpha$-MEM or NCSU media.

\begin{tabular}{|c|c|c|c|c|c|c|c|c|c|}
\hline \multirow[t]{2}{*}{ Treatments (n) } & \multicolumn{3}{|c|}{ \% Morphologically normal follicles } & \multicolumn{3}{|c|}{ \% Follicular extrusion } & \multicolumn{3}{|c|}{ \% Follicular degeneration } \\
\hline & Day 0 & Day 2 & Day 4 & Day 0 & Day 2 & Day 4 & Day 0 & Day 2 & Day 4 \\
\hline$\alpha$-MEM (35) & $100(35 / 35)^{\mathrm{a}}$ & $100(35 / 35)^{\mathrm{a}}$ & $88.57(31 / 35)^{b}$ & $0(0 / 35)$ & $0(0 / 35)$ & $2.86(1 / 35)$ & $0(0 / 35)$ & $0(0 / 35)$ & $8.57(3 / 35)$ \\
\hline NCSU (30) & $100(30 / 30)^{\mathrm{a}}$ & $100(30 / 30)^{\mathrm{a}}$ & $86.67(26 / 30)^{\mathrm{b}}$ & $0(0 / 30)$ & $0(0 / 30)$ & $3.33(1 / 30)$ & $0(0 / 30)$ & $0(0 / 30)$ & $10(3 / 30)$ \\
\hline
\end{tabular}

a,b Values with different suberscripts differ between days of culture $(\mathrm{P}<0.05)$ and between the treatments within the culture time $(\mathrm{P}>0.05)$. Source: Authors $(2021)$.

Table 2 - Antrum formation (\%) and follicular growth $\underline{(\mu \mathrm{m})}$ after 4 days of culture in $\alpha$-MEM or NCSU media.

\begin{tabular}{|c|c|c|c|c|c|c|c|}
\hline \multirow[t]{2}{*}{ Treatments (n) } & \multicolumn{3}{|c|}{ \% Antrum formation } & \multicolumn{3}{|c|}{ Follicular diameter $(\mu \mathrm{m})$} & \multirow[t]{2}{*}{ Daily growth rate $(\mu \mathrm{m})$} \\
\hline & Day 0 & Day 2 & Day 4 & Day 0 & Day 2 & Day 4 & \\
\hline$\alpha-\operatorname{MEM}(35)$ & $0(0 / 35)$ & $68.57(24 / 35)^{\mathrm{a} \#}$ & $74.29(26 / 35)^{\mathrm{a}}$ & $290.17 \pm 33.16^{\mathrm{b}}$ & $297.90 \pm 46.98^{\mathrm{ab}}$ & $318.72 \pm 61.79^{a}$ & $7.95 \pm 12.14$ \\
\hline NCSU (30) & $0(0 / 30)$ & $46.67(14 / 30)^{\mathrm{a}}$ & $60.00(18 / 30)^{\mathrm{a}}$ & $274.74 \pm 38.21^{b}$ & $284.04 \pm 45.11^{\mathrm{b}}$ & $310.64 \pm 58.57^{\mathrm{a}}$ & $6.06 \pm 13.05$ \\
\hline
\end{tabular}

Data (follicular diameter and growth rate) are mean \pm SEM.

${ }_{a, b}$ Values with different suberscripts differ between days of culture $(\mathrm{P}<0.05)$ and between the treatments within the culture time $(\mathrm{P}>0.05)$

\# Indicates values that approached significant differences between the treatments $(\mathrm{P}<0.074)$.

Source: Authors (2021).

\subsection{Experiment I: Steroid Production}

As can be seen in Figure 1 at Day 4 of culture, the estradiol and progesterone secretion were higher in $\alpha$-MEM than NCSU23 (P < 0.01 ), while the opposite was observed for testosterone production $(\mathrm{P}<0.01)$. 
Figure 1 - Steroid production (mean \pm SEM) by porcine preantral follicles cultured in vitro for 4 days in $\alpha$-MEM or NCSU media.

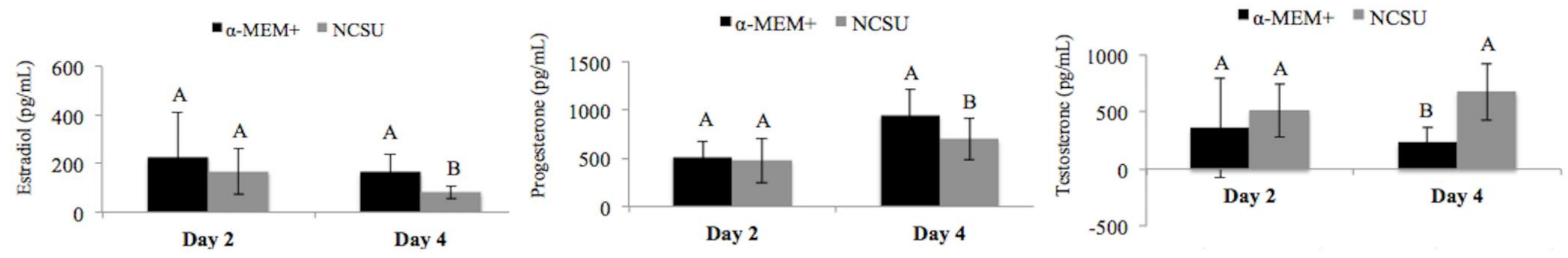

A,B Values with different suberscripts differ between the treatments within the same day of culture $(\mathrm{P}<0.01)$. Source: Authors $(2021)$.

\subsection{Experiment II: Follicle Survival and Growth}

At day 2 of culture, the percentage of morphologically normal follicles was lower in AMH alone than control (P < 0.05), while at day 4 no difference was observed among the

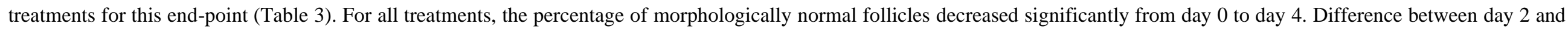

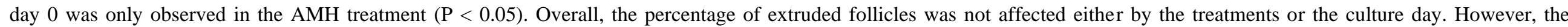

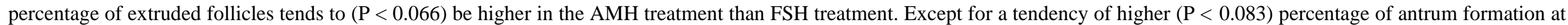

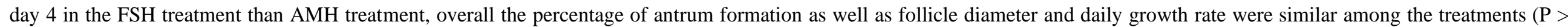

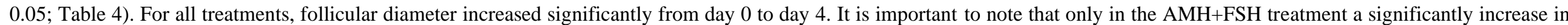
follicle diameter was observed from day 0 to day 2. 
Research, Society and Development, v. 10, n. 15, e53101522488, 2021

(CC BY 4.0) | ISSN 2525-3409 | DOI: http://dx.doi.org/10.33448/rsd-v10i15.22488

Table 3 - Percentage of morphologically normal, extruded and degenerated follicles after 4 days of culture in $\alpha$-MEM supplemented with AMH and/or FSH.

\begin{tabular}{|c|c|c|c|c|c|c|c|c|c|}
\hline \multirow[t]{2}{*}{ Treatments (n) } & \multicolumn{3}{|c|}{ \% Morphologically normal follicles } & \multicolumn{3}{|c|}{ \% Follicular extrusion } & \multicolumn{3}{|c|}{ \% Follicular degeneration } \\
\hline & Day 0 & Day 2 & Day 4 & Day 0 & Day 2 & Day 4 & Day 0 & Day 2 & Day 4 \\
\hline$\alpha-\operatorname{MEM}(40)$ & $100(40 / 40)^{\mathrm{Aa}}$ & $100(40 / 40)^{\mathrm{Aa}}$ & $82.50(33 / 40)^{\mathrm{Ab}}$ & $0(0 / 40)$ & $0(0 / 40)$ & $5.00(2 / 40)$ & $0(0 / 40)$ & $0(0 / 40)$ & $12.5(5 / 40)$ \\
\hline FSH (40) & $100(40 / 40)^{\mathrm{Aa}}$ & $92.5(37 / 40)^{\mathrm{ABab}}$ & $82.50(33 / 40)^{\mathrm{Ab}}$ & $0(0 / 40)$ & $2.50(1 / 40)$ & $2.50(1 / 40)$ & $0(0 / 40)$ & $5(2 / 40)^{\mathrm{a}}$ & $15(6 / 40)^{\mathrm{a}}$ \\
\hline AMH (45) & $100(45 / 45)^{\mathrm{Aa}}$ & $88.89(40 / 45)^{\mathrm{Bb}}$ & $80.00(36 / 45)^{\mathrm{Ab}}$ & $0(0 / 45)$ & $11.00(5 / 45)$ & $13.33(6 / 45)^{\#}$ & $0(0 / 45)$ & $0(0 / 45)$ & $6,67(3 / 45)$ \\
\hline $\mathrm{AMH}+\mathrm{FSH}(45)$ & $100(45 / 45)^{\mathrm{Aa}}$ & $95.56(43 / 45)^{\mathrm{ABa}}$ & $77.78(35 / 45)^{\mathrm{Ab}}$ & $0(0 / 45)$ & $2.22(1 / 45)$ & $6.67(3 / 45)$ & $0(0 / 45)$ & $2.22(1 / 45)^{\mathrm{b}}$ & $15.56(7 / 45)^{\mathrm{a}}$ \\
\hline
\end{tabular}

A,B Values with different suberscripts differ between treatments $(\mathrm{P}<0.05)$. ${ }^{\mathrm{a}, \mathrm{b}}$ Values with different suberscripts differ between days of culture $(\mathrm{P}<0.05)$.

\# Indicates values that approached significant differences between the treatments $(\mathrm{P}<0.066)$.

Source: Authors (2021)

Table 4 - Antrum formation (\%) and follicular growth $(\mu \mathrm{m})$ after 4 days of culture in $\alpha$-MEM supplemented with AMH and/or FSH.

\begin{tabular}{|c|c|c|c|c|c|c|c|}
\hline \multirow[t]{2}{*}{ Treatments (n) } & \multicolumn{3}{|c|}{ \% Antrum formation } & \multicolumn{3}{|c|}{ Follicular diameter $(\mu \mathrm{m})$} & \multirow[t]{2}{*}{ Daily growth rate $(\mu \mathrm{m})$} \\
\hline & Day 0 & Day 2 & Day 4 & Day 0 & Day 2 & Day 4 & \\
\hline$\alpha-\operatorname{MEM}(40)$ & $0(0 / 40)$ & $52.50(21 / 40)$ & $52.5(21 / 40)$ & $280.81 \pm 20.00^{\mathrm{b}}$ & $286.79 \pm 35.76^{\mathrm{b}}$ & $304.24 \pm 38.09^{\mathrm{a}}$ & $3.41 \pm 9.93$ \\
\hline FSH (40) & $0(0 / 40)$ & $67.50(27 / 34)$ & $67.50(27 / 40)^{\#}$ & $284.58 \pm 19.94^{\mathrm{b}}$ & $285.06 \pm 31.14^{\mathrm{b}}$ & $301.20 \pm 34.31^{\mathrm{a}}$ & $3.88 \pm 7.42$ \\
\hline $\mathrm{AMH}(45)$ & $0(0 / 45)$ & $48.89(22 / 45)$ & $48.89(22.45)$ & $283.81 \pm 20.98^{b}$ & $289.83 \pm 29.83^{\mathrm{b}}$ & $303.47 \pm 27.74^{\mathrm{a}}$ & $4.46 \pm 6.82$ \\
\hline AMH + FSH (45) & $0(0 / 45)$ & $57.78(26 / 45)$ & $57.78(26 / 45)$ & $282.61 \pm 18.24^{\mathrm{b}}$ & $294.90 \pm 28.71^{\mathrm{a}}$ & $303.06 \pm 30.29^{a}$ & $5.25 \pm 9.49$ \\
\hline
\end{tabular}

Data (follicular diameter and growth rate) are mean \pm SEM.

a,b Values with different suberscripts differ between days of culture $(\mathrm{P}<0.05)$ and between the treatments within the culture time $(\mathrm{P}>0.05)$.

\# Indicates values that approached significant differences between the treatments $(\mathrm{P}<0.08)$. Source: Authors $(2021)$. 
Regardless the culture day FSH treatment showed a higher $(\mathrm{P}<0.01)$ estradiol production when compared to the other treatments (Figure 2). At day 2 of culture, progesterone

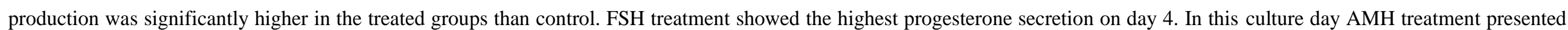

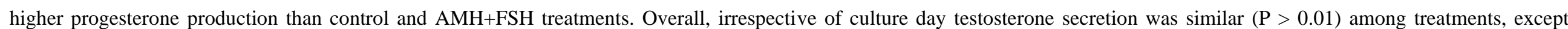
between $\mathrm{AMH}$ and $\mathrm{AMH}+\mathrm{FSH}$ treatments on day $4(\mathrm{P}<0.01)$.

Figure 2 - Steroid production (mean \pm SEM) by porcine preantral follicles cultured in vitro for 4 days in $\alpha$-MEM supplemented with AMH and/or FSH.

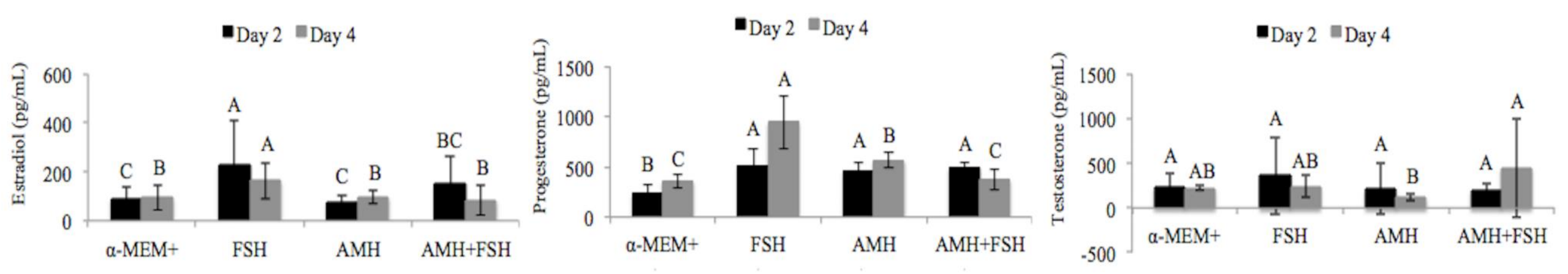

A,B,C Values with different suberscripts differ between the treatments within the same day of culture $(\mathrm{P}<0.01)$. Source: Authors $(2021)$.

\section{Discussion}

The in vitro culture of isolated pig pre-antral follicles has been performed using $\alpha$-MEM (Mao et al., 2004; Lima et al., 2017; Rubessa, Rocha, Lima, Winters, Figueiredo, \&

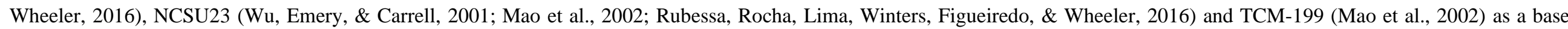

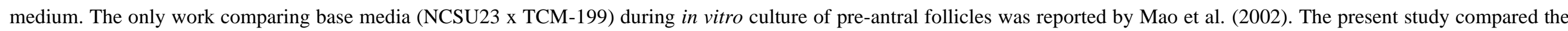

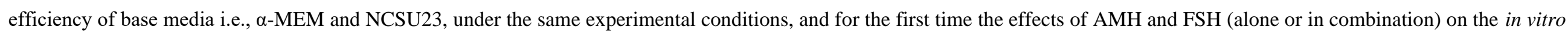

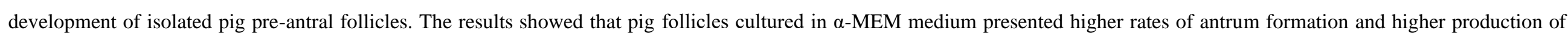

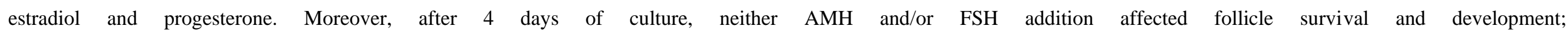


however, it was observed that AMH reduced the production of estradiol and progesterone induced by FSH.

In the present study, both base media ( $\alpha$-MEM and NCSU23) presented similar follicular survival and growth rates. On Day 2, $\alpha$-MEM increased antrum formation compared to NCSU23, this could be explained by the richer formulation of $\alpha$ MEM, which contains essential amino acids, vitamins, inorganic acids, pyruvate, ribonucleosides, and deoxyribonucleosides compared with NCSU23 (inorganic salts and energy sources), since $\alpha$-MEM may provide better conditions to the in vitro follicular development.

When we went to evaluate steroid hormone production, we found a higher estradiol and progesterone secretion in $\alpha$ MEM than NCSU23, however, on the other hand in NCSU23 we found a high concentration of testosterone. It is important to remember the pathway for the hormone production during folliculogenesis, where androgens (testosterone) are converted to estrogens (estradiol) under P450 aromatase action (Valdez \& Turzillo, 2005; Linardi, Damiani, \& Longui, 2017). It can be suggested from the present results that a higher secretion of androgens observed in the presence of NCSU23 medium, was not followed by an increase in estrogen production, suggesting a lack of appropriate expression of P450 aromatase.

The second part of this study examined anti-Müllerian hormone effects on the follicle development. Previous studies performed in mice (Durlinger et al., 2001; Park, Maclaughlin, \& Teixeira, 2011) reported that AMH decreased follicular growth but did not affect follicular survival. In our results, a lower percentage of morphologically normal follicles was observed when AMH was added on Day 2 of culture. Increased follicular integrity and antrum formation were observed in the presence of FSH alone which, was not observed with AMH. Previous work performed in goats found that in the presence of FSH alone, there was a reduction in the mRNA expression for AMH receptor type II (AMHRII; Rocha et al., 2016). Thus, based on this findings, we suggest that the increased antrum formation and follicular integrity in this experiment may be due to: 1) a reduction in the action of endogenous AMH caused by the lower levels of AMHRII in the presence of FSH; and 2) the addition of FSH to the culture medium possibly stimulates the expression of many important growth factors, which may improve follicular survival and growth.

Regarding hormone production, in our study AMH plus FSH showed a reduced amount of estradiol and progesterone production compared with FSH group. During in vivo folliculogenesis, AMH would affect the growth process of late pre-antral and early antral follicles, attenuating FSH effects (Durlinger et al., 2001; Dewailly et al., 2016). One mechanism behind this suppression of follicular growth could be the reduction of estradiol secretion stimulated by FSH (Chang, Klausen, \& Leung, 2013), probably caused by a reduction in aromatase expression as well as FSH receptor induced by AMH addition (Di Clement et al., 1994; Pellatt et al., 2011; Sacchi et al., 2016). These experiments have increased our knowledge regarding in vitro porcine pre-antral follicle culture.

\section{Final Considerations}

In conclusion, we have shown that $\alpha$-MEM is the most suitable base medium for the in vitro culture of isolated pig pre-antral follicles because the follicles had increased follicular development and estradiol secretion as opposed to culture in NCSU23. Furthermore, the second part of the study showed that AMH reduced estradiol and progesterone production induced by FSH and, combining FSH and AMH do not affect either follicle survival or development. However, more studies are needed to unravel the mechanism by which AMH affects FSH-induced steroid production during in vitro culture of pig preantral follicles. 
Research, Society and Development, v. 10, n. 15, e53101522488, 2021

(CC BY 4.0) | ISSN 2525-3409 | DOI: http://dx.doi.org/10.33448/rsd-v10i15.22488

\section{Acknowledgments}

This work was partially funded by the University of Illinois Experiment Station and the U.S. Department of Agriculture-National Institute of Food and Agriculture via Multistate Research Project W-2171, \#ILLU-538-347 (to Wheeler MB). Rebeca Magalhães Pedrosa Rocha would like to thank the Coordenação de Aperfeiçoamento de Pessoal de Nível Superior (CAPES) for granting her research grant.

\section{References}

Cao, Z., Gao, D., Tong, X., Xu, T., Zhang, D., Wang, Y., Liu, Y., Li, Y., Zhang, Y., \& Pu, Y. (2019). Melatonin improves developmental competence of oocyte-granulosa cell complexes from porcine preantral follicles. Theriogenology, 133, 149-158.

Carlsson, I. B., Scott, J. E., Visser, J. A., Ritvos, O., Themmen, A. P., \& Hovatta, O. (2006). Anti-Müllerian hormone inhibits initiation of growth of human primordial ovarian follicles in vitro. Human Reproduction, 21, 2223-2227.

Chang, H. M., Klausen, C., \& Leung, P. C. (2013). Anti-müllerian hormone inhibits follicle-stimulating hormone-induced adenylyl cyclase activation, aromatase expression, and estradiol production in human granulosa-lutein cells. Fertility and Sterility, 100, $585-592$.

Dewailly, D., Robin, G., Peigne, M., Decanter, C., Pigny, P., \& Catteau-Jonard, S. (2016). Interactions between androgens, FSH, anti-Müllerian hormone and estradiol during folliculogenesis in the human normal and polycystic ovary. Human Reproduction Update, 22, 6, 709-724.

Di Clemente, N., Wilson, C., Faure, E., Boussin, L., Carmillo, P., Tizard, R., Picard, J. Y., Vigier, B., Josso, N., \& Cate, R. (1994). Cloning, expression, and alternative splicing of the receptor for anti-Müllerian hormone. Molecular Endocrinology, 1006-1020.

Durlinger, A. L., Gruijters, M. J., Kramer, P., Karels, B., Kumar, T. R., Matzuk, M. M., Rose, U. M., Jong, F. H., Uielenbroek, J. T., Grootegoed, J. A., \& Themmen, A. P. (2001). Anti-Müllerian hormone attenuates the effects of FSH on follicle development in the mouse ovary. Endocrinology, 142, 4891-4899.

Durlinger, A. L. L., Gruijters, M. J. G., Kramer, P., Karels, B., Ingraham, H. A., Nachtigal, M. W., Uilenbroek, J. T. J., \& Grootegoed, J. A. (2002). AntiMüllerian hormone inhibits initiation of primordial follicle growth in the mouse ovary. Endocrinology, 143, 1076-1084.

Figueiredo, J. R., Rodrigues, A. P. R., Silva, J. R. V., \& Santos, R. R. (2011). Cryopreservation and in vitro culture of caprine preantral follicles. Reproduction, Fertility and Development, 23, 1, 40-47.

Kano, M., Sosulski, A. E., Zhang, L., Saatcioglu, H. D., Wang, D., Nagykery, N., Sabatini, M. E., Gao, G., \& Donahoe, P. K. (2017). AMH/MIS as a contraceptive that protects the ovarian reserve during chemotherapy. Proceedings of the National Academy of Sciences, 114,9 , E1688-E1697.

Lima, L. F., Rubess, M., Rocha, R., Winters, R., Milner, D. J., Campello, C. C., Figueiredo, J. R., \& Wheeler, M. B. (2017). High diluted and dynamised follicle stimulating hormone modulates steroid production in isolated porcine preantral follicles cultured in vitro. Homeopathy, 106, 2 , 87-92.

Linardi, A., Damiani, D., \& Longui, C. A. (2017). The use of aromatase inhibitors in boys with short stature: what to know before prescribing? Arch Endocrinology and Metabolism, 61, 4, 391-397.

Mao, J., Wu, G., Smith, M. F., McCauley, T. C., Cantley, T. C., Prather, R. S., Didion, B. A., \& Day, B. N. (2002). Effects of culture medium, serum type, and various concentrations of follicle-stimulating hormone on porcine preantral follicular development and antrum formation in vitro. Biology of Reproduction, 67 , 1197-1203.

Mao, J., Smith, M. F., Rucker, E. B., Wu, G. M., McCauley, T. C., Cantley, T. C., Prather, R. S, Didion, B. A., \& Day, B. N. (2004). Effect of epidermal growth factor and insulin-like growth factor I on porcine preantral follicular growth, antrum formation, and stimulation of granulosa cell proliferation and suppression of apoptosis in vitro. Journal of Animal Science, 82, 7, 1967-1975.

Marino, P. C., Bizarro-Silva, C., Búfalo, I., Rosa, C. O., Gonçalves, G. R., Lisboa, L. A., \& Seneda, M. M. (2019). Growth and Differentiation Factor-9 Supplementation Affects Viability and Morphology of Preantral Follicles in Equine Ovarian Fragments During Short-term In vitro Culture. Brazilian Archives of Biology and Technology, 62.

Nilsson, E. E., Schindler, R., Savenkova, M. I., \& Skinner, M. K. (2011). Inhibitory actions of Anti-Müllerian Hormone (AMH) on ovarian primordial follicle assembly. PloS One, 5, e20087.

O’Brien, M. J., Pendola, J. K., \& Eppig, J. J. (2003). A revised protocol for in vitro development of mouse oocytes from primordial follicles dramatically improves their developmental competence. Biology of Reproduction, 68, 5, 1682-1686.

Park, J. H., Maclaughlin, D. T., \& Teixeira, J. M. (2011). The rate of in vitro maturation of primary follicles from adult mice and the quality of oocytes is improved in the absence of anti-mullerian hormone. Reproductive Sciences, 18, 334-341.

Pankhurst, M. W. (2017). A putative role for anti-Müllerian hormone (AMH) in optimising ovarian reserve expenditure. Journal Endocrinology, 233, 1, R1R13.

Pankhurst, M. W., Kelley, R. L., Sanders, R.L., Woodcock, S. R., Oorschot, D. E., \& Batchelor, N. J. (2018). Anti-Müllerian hormone overexpression restricts preantral ovarian follicle survival. Journal Endocrinology, 237, 2, 153-163. 
Research, Society and Development, v. 10, n. 15, e53101522488, 2021

(CC BY 4.0) | ISSN 2525-3409 | DOI: http://dx.doi.org/10.33448/rsd-v10i15.22488

Pellatt, L., Rice, S., Dilaver, N., Heshri, A., Galea, R., Brincat, M., Brown, K., Simpson, E. R., \& Mason, H. D. (2011). Anti-Müllerian hormone reduces follicle sensitivity to follicle-stimulating hormone in human granulosa cells. Fertility and Sterility, 96, 1246-1251.

Pyoos, G. M., Maqhashu, A. M., Scholtz, M. M., \& Nedambale, T. L. (2018). The comparison of three media on the in vitro maturation rate of pig oocytes. South African Journal of Animal Science, 48, 1027.

Rocha, R. M. P., Lima, L. F., Brito, I. R., Silva, G. M., Correia, H. H., Sá, N. A. R., Ferreira, A. C. A., Sales, A. D., Lobo, C. H., Campello, C. C., Smitz, J. S., Wheeler, M. B., \& Figueiredo, J. R. (2016). Anti-Müllerian hormone reduces growth rate without altering follicular survival in isolated caprine preantral follicles cultured in vitro. Reproduction, Fertility and Development, 29, 1144-1154

Rubessa, M., Rocha, R., Lima, L., Winters, R., Figueiredo, J., \& Wheeler, M. (2016). 136 Comparison of NCSU-23 and Alpha-Minimal Essential Media in the Development of Isolated Porcine Preantral Follicles In vitro. Reproduction, Fertility and Development, $28,1,198$.

Sacchi, S., D'Ippolito, G., Sena, P., Marsella, T., Tagliasacchi, D., Maggi, E., Argento, C., Tirelli, A., Giulini, S., La, \& Marca. A. (2016). The anti-Müllerian hormone (AMH) acts as a gatekeeper of ovarian steroidogenesis inhibiting the granulosa cell response to both FSH and LH. Journal of Assisted Reproduction and Genetics, 33, 1, 95-100.

Schmidt, K. L., Kryger-Baggesen, N., Byskov, A. G., \& Andersen, C. Y. (2005). Anti-Müllerian hormone initiates growth of human primordial follicles in vitro. Molecular and Cellular Endocrinology, 234, 87-93.

Sonigo, C., Beau, I., Grynberg, M., \& Binart, N. (2019). AMH prevents primordial ovarian follicle loss and fertility alteration in cyclophosphamide-treated mice. The FASEB Journal, 33, 1, 1278-1287.

Tasaki, H., Iwata, H., Sato, D., Monji, Y., \& Kuwayama, T. (2013). Estradiol has a major role in antrum formation of porcine preantral follicles cultured in vitro. Theriogenology, 79, 809-814.

Valdez, K. E., \& Turzillo, A. M. (2005). Regulation of nuclear factor-kappaB (NF-kappaB) activity and apoptosis by estradiol in bovine granulosa cells. Molecular and Cellular Endocrinology, 243, 66-73.

Wu, J., Emery, B. R., \& Carrell, D. T. (2001). In vitro growth, maturation, fertilization, and embryonic development of oocytes from porcine preantral follicles. Biology of Reproduction, 64, 1, 375-381.

Wu, J., Xu, B., \& Wang, W. (2007). Effects of luteinizing hormone and follicle stimulating hormone on the developmental competence of porcine preantral follicle oocytes grown in vitro. Journal of Assisted Reproduction and Genetics, 24, 419-424.

Yu, X. X., Liu, Y. H., Liu, X. M., Wang, P. C., Liu, S., Miao, J. K., Du, Z. Q., \& Yang, C. X. (2018). Ascorbic acid induces global epigenetic reprogramming to promote meiotic maturation and developmental competence of porcine oocytes. Scientific Reports, 8(1), 6132. 